\title{
Allergy to Dermatophagoides pteronyssinus (Der p1) and Dermatophagoides farina (Der f1) in Patients with Atopic Asthma
}

\author{
Osama H. Abd Ella ${ }^{1}$, El Kady A. M., Badawy ${ }^{2}$, Mohammed Shahat ${ }^{3}$, Amal M. Ahmed ${ }^{4}$, \\ Alaa Rashad ${ }^{5}$, Dr. Omran E. Khalf ${ }^{6}$ \\ ${ }^{1}$ Lecturer of Medical Parasitology, Faculty of Medicine Qena, South Valley University \\ ${ }^{2}$ Lecturer of Medical Parasitology, Faculty of Medicine Qena, South Valley University \\ ${ }^{3}$ Assistant professor of Chest Disease, Faculty of Medicine, South Valley University \\ ${ }^{4}$ Lecturer of Medical Parasitology, Faculty of Medicine, Sohag University \\ ${ }^{5}$ Lecturer Chest Disease, Faculty of Medicine, Sohag University \\ ${ }^{6}$ Lecturer, Medical Parasitology Department Faculty of Medecine, Sohag University, Egypt
}

\begin{abstract}
Background: House dust mites (HDMs) are important sources of indoor allergens. The prevalence of sensitization to HDM in atopic patients is around $70 \%$ to $90 \%$ worldwide. Objective: Our aim was to measure the specific IgE to components of Der pland Der $f 1$ in asthmatic patients at Qena Governorate, Egypt. Methods: We performed a prospective evaluation of 48 HDM sensitized asthmatic patients with positive skin prick test to Dermatophagoides pteronyssinus (Der p) and Dermatophagoides farina (Der f). Patients underwent Immuno CAP for specific IgE to Der p 1, Der $f$ 1. Results: Skin prick test were done to 132 patients asthma with attending to Qena University Hospital to Dermatophagoides pteronyssinus (Der p) and Dermatophagoides farina (Der f) and other allergenic components, also skin prick test were done to 38 healthy people as a control group. Skin prick test were positive in 48 patients (36. 36\%) ( $P$ value is < 0.015). Forty-eight asthmatic patients had detectable serum specific IgE to Der $p$ and Der $f$ by ImmunoCAP assay. There was a significant positive correlation between skin prick test and specific IgE to Der p1 and Der f1 (P value is 0.000$)$.According to sex there was a highly correlation among sensitivity to Der $p 1$ and Der $f 1$ in both males and females $(P$ value is 0.000$)$, also there were a highly significant relation among sensitivity to Der $p 1$ and Der f1(P value is 0.000$)$ and residence (rural $r$ urban)of the studied patients. Conclusion: Sensitization to HDM especially Dermatophagoides pteronyssinus (Der p) and Dermatophagoides farinae (Der $f$ ) is similar to previous studies. Determination of Der $p 1$ and Der f1 specific IgE helps in obtaining additional information in regards to atopic asthma and other allergic diseases.
\end{abstract}

Keywords: Egypt, Patient, Asthma, Dermatophagoides pteronyssinus, Dermatophagoides farinae, Immuno CAP.

\section{Introduction}

House dust mites (HDM) are major source of inhalant allergens responsible for allergic asthma Spieksma and Dieges, (2004). There are many species of dust mites infested in and around the houses worldwide Dermatophagoides pteronyssinus (Dp) and Dermatophagoides farina (Df) are of the most common house dust mites (HDMs) Arlian and Platts-Mills (2001).

Extensive studies have been done to understand the biological, chemical and structural properties of such mite allergens and most characterized allergens are from Dermatophagoides farina (Df) and Dermatophagoides pteronyssinus (Dp) that are coexisting in most geographical regions (Yasue et al., 1998 and Platts-Mills et al., 1992). Secretions, feces and body degradation products of HDM can cause human allergic diseases (Arlian and Platts-Mills, 2001and Fernandez-Caldas, 2002).

Type I allergic diseases, including allergic asthma, allergic rhinitis and atopic dermatitis are increasingly prevalent, and becoming one of global health problems, which affected as high as $10 \%$ to $30 \%$ of the world population (Ferreira et al., 2002). Asthma is a chronic airway inflammatory disease, characterized by lung leukocyte and eosinophilic infiltration accompanied by mucus hypersecretion and airway hyperresponsiveness ( $\mathrm{Li}$ and Hua (2014) and kim et al., 2010), and closely associated with activated T cells in the lung. Development of asthma depends on an interaction between genetic factors and environmental allergens, especially house dust mites (HDM) (Sporik et al., 1990 and Lau et al., 2000). Allergic exposure leads to sensitization, and sensitization to HDM is an important risk factor for the development of asthma in childhood Wahn et al., (1997). The prevalence of sensitization to HDM in atopic patients is around $70 \%$ to 90\% worldwide Montealegre et al., (2004)

\section{Aim of the Work}

Aim of the prospective study to assess the role of House Dust Mites (HDM), Dermatophagoides pteronyssinus (Der p1) and Dermatophagoides farina (Der fl) in asthmatic patients at Qena Governorate by skin prick test and also to measure by Immuno CAP assay specific IgE to 


\section{International Journal of Science and Research (IJSR) \\ ISSN (Online): 2319-7064}

Index Copernicus Value (2013): 6.14 | Impact Factor (2014): 5.611

Der $\mathrm{p}$ 1and Der $\mathrm{f} 1$ in the studied asthmatic patients and control group.

\section{Material and Methods}

132 patients (65 males and 67 females), 21children (5-15 years) and the rest were adults and according to residence 68 were from rural areas and 64 from urban areas, those patients attending to Chest Disease Department outpatient clinic, Pediatric outpatient clinic and inpatients of this departments complaining from chronic or recurrent cough with wheezy chest and diagnosed as bronchial asthma. The diagnosis of asthma was based on the criteria of the 2002 Global Initiative for Asthma (GINA) guidelines (National Institutes of Health, National Heart, Lung, and Blood Institute, 2002). All patients enrolled for analysis of percentage of sensitization to indoor allergens had positive results to the methacholine bronchial provocation test. Also 38 healthy people recruited in the study as a control group. Skin prick test were done to all enrolled patients and control group in the study, the antigens used for skin prick test were Dermatophagoides farinae and Dermatophagoides pteronyssinus, Aspegillus fumigatus, Penicillium notatum, Candida albicans, Grass pollen, hay dust, duck and pigeon feather, bird excreta, cat and dog hair, and cockroach extract. Histamine phosphate $(5 \mathrm{mg} / \mathrm{ml}$, as a positive control) and negative control solution were also used (the antigens and positive and negative controls were supplied by the Allergopharma Joachim Ganzer KG company). The test was considered positive if the mean diameter of the wheal at 15 minutes was $>3 \mathrm{~mm}$ than the negative control. 48 asthmatic patients were with positive skin prick test to House Dust Mites (HDM), Dermatophagoides pteronyssinus (Derp1)and Dermatophagoides farinae (Der f1) were enrolled in the study and blood samples for IgE assay of ImmunoCAP (Pharmacia CAP System; Pharmacia Diagnostics AB, Uppsala, Sweden) Paganelli et al., (1998). The studied patient's and control divided to four groups according to age as flowing 5-15 years 7 cases, $15-30$ years 30 cases, $30-45$ years 24 cases and $45-60$ years.

Blood samples were taken by venipuncture using anticoagulant-free tubes to obtain serum for antibody determinations Specific IgE levels against Dermatophagoides pteronyssinus (Der p1) and Dermatophagoides farinae (Der f1).

Specific serum Ig E Der p1 crude extract, Der f1 crude extract, Der $\mathrm{p} 1$ and Der f1 were measured with the ImmunoCAP immunofluorimetric assay, components and reagents (Thermo Fisher Scientific, Immuno Diagnostics, Uppsala, Sweden). Measures of total IgE levels were expressed in international units per unit volume $(\mathrm{IU} / \mathrm{mL}, 1$ IU equals $2.4 \mathrm{ng}$ ). Specific IgE levels were expressed in arbitrary units per unit volume (IU/mL). The measuring range of total $\mathrm{IgE}$ was between 2 and $5,000 \mathrm{IU} / \mathrm{mL}$ and that of specific IgE to Der $p$ extract and molecular components were between 0 and $100 \mathrm{IU} / \mathrm{mL}$. In case a measure was too high for the measuring range, we assumed $\mathrm{IgE}$ to be $100 \mathrm{IU} / \mathrm{mL}$. The Immuno CAP 250 machine underwent monthly quality controls (Euro EQAS for Total IgE, Euro EQAS for Specific IgE, Phadia Quality Club for specific IgE).

The Pharmacia CAP system defines seven quantitative classes by the following criteria:

Class 0 , below $0.35 \mathrm{kUA} / 1$.

Class $1,0.35$ to $0.7 \mathrm{kUA} / 1$.

Class $2,0.7$ to $3.5 \mathrm{kUA} / \mathrm{l}$.

Class 3, 3.5 to $17.5 \mathrm{kUA} / 1$.

Class $4,17.5$ to $50 \mathrm{kUA} / 1$.

Class 5, 50 to $100 \mathrm{kUA} / \mathrm{l}$.

Class 6, above $100 \mathrm{kUA} / \mathrm{l}$.

A value of $0.35 \mathrm{kUA} / 1$ or above is identified as a positive result and considered positive sensitization to allergen Pastorello et al., (1995) and Official abstracts of papers of the XIII International Congress of Allergology and Clinical Immunology (ICACI) (1988).

The Immuno CAP results were analyzed to investigate the percentage of sensitization to HDM (positive results of specific $\operatorname{IgE}$ assay for both Der p1 and Der f1). Demographic characteristics including age, gender and residence were evaluated for associations with the percentage of allergic sensitization. The studied 48 asthmatic patients and 16 from 34 with negative skin prick test to HDM were randomly recruited in the study as a control group, divided into 4 age groups as following: 5-15 years ( 7 patients), 15-30 years (25 patients and 5 controls), $30-45$ years (14 patients and 10 controls) and $45-60$ years ( 2 patients and 1 control). The residential variables were classified as urban (30 patients and controls) and rural (34 patients and controls).

Stool samples from all patients and control group were macroscopically examined. Then, the samples were microscopically examined as the stained direct smear and by sedimentation and Kato-Katz techniques to exclude helminthic infection (Katz et al., 1972).

\section{Statistical Analysis}

Data are expressed as the mean $\pm \mathrm{SD}$, and were analyzed using SPSS 16.0 software (SPSS, Inc., Chicago, IL, USA). The chi-square test or Fisher's exact test were used to examine the percentage difference of sensitization to individual allergens within different age groups, gender and residential variables. The chi- square test was used to compare the percentage difference of sensitization to HDM among age groups, gender and residence. $\mathrm{P}$ value is $<0.05$ was considered to indicate a statistically significant result.

The study was approved by the Ethical Committee of South Valley University Qena Faculty of medicine. Signed informed consent was obtained from patients or their parents.

\section{Results}

The study period, 132 asthmatic patients adults and children who visited the Out Patients Clinics (Chest Disease Department and pediatric Department) of Qena University Hospital and /or admitted to this department.

\section{Volume 4 Issue 11, November 2015}




\section{International Journal of Science and Research (IJSR) \\ ISSN (Online): 2319-7064 \\ Index Copernicus Value (2013): 6.14 | Impact Factor (2014): 5.611}

All the studied patients diagnosed as asthma according to (GINA) guidelines, skin prick test were done to them and it was positive to HDM in 48 patients (36. 36\%). Within the 48 patients sensitized to HDM, 13 were found to be with low positive skin prick test, 14 were found to be with moderate positive skin prick test and 21 were found to be with high positive skin prick test, while in control group (38), it was 2 were found to be with low positive skin prick test and 2 were found to be with moderate positive skin prick test with significant relation between skin prick test in asthmatic patients in comparison control group ( $\mathrm{P}$ value is 0.015). Specific IgE levels for Dermatophagoides pteronyssinus (Der p1) and Dermatophagoides farinae (Der f1) were analyzed to all studied patient's and controls who were divided into four groups according to age as following 5-15 years 7cases, 15-30 years 30 cases, 3045years 24 cases and 45-60 years and specific IgE to Der The following tables showing results of the present study:

Table 1: Skin prick test results of the studied cases and control groups

\begin{tabular}{|c|c|c|c|c|c|c|}
\hline & \multicolumn{4}{|c|}{ Skin prick test } & \multirow{2}{*}{ Total } & \multirow{2}{*}{$P$ value } \\
\hline & $-\mathrm{Ve}$ & High & Moderate & Low & & \\
\hline Case & 84 & 21 & 14 & 13 & 132 & \\
\hline Control & 34 & 0 & 2 & 2 & 38 & .015 \\
\hline Total & 118 & 21 & 16 & 15 & 170 & \\
\hline
\end{tabular}

Table 2: Skin prick test and specific IgE in asthmatic and control groups

\begin{tabular}{|c|c|c|c|c|c|c|c|c|}
\hline & & & \multicolumn{4}{|c|}{ Skin Test } & \multirow[b]{2}{*}{ Total } & \multirow[t]{2}{*}{$\mathrm{P}$ value } \\
\hline & \multicolumn{2}{|l|}{ Case-control } & $-\mathrm{Ve}$ & Low & Moderate & High & & \\
\hline \multirow[t]{8}{*}{ Case } & \multirow[t]{7}{*}{ Test Results } & Class 0 & 0 & 4 & 0 & 0 & 4 & \\
\hline & & Class 1 & 0 & 8 & 4 & 0 & 12 & \\
\hline & & Class 2 & 0 & 4 & 6 & 0 & 10 & \\
\hline & & Class 3 & 0 & 0 & 6 & 0 & 6 & .000 \\
\hline & & Class 4 & 0 & 0 & 5 & 1 & 6 & \\
\hline & & Class 5 & 0 & 0 & 2 & 3 & 5 & \\
\hline & & Class 6 & 0 & 0 & 0 & 5 & 5 & \\
\hline & \multicolumn{2}{|c|}{ Total } & 0 & 9 & 23 & 9 & 9 & \\
\hline \multirow[t]{8}{*}{ Control } & \multirow[t]{7}{*}{ Test Results } & Class 0 & 12 & 0 & 0 & 0 & 12 & \\
\hline & & Class 1 & 1 & 0 & 0 & 0 & 1 & \\
\hline & & Class 2 & 3 & 0 & 0 & 0 & 3 & \\
\hline & & Class 3 & 0 & 0 & 0 & 0 & 0 & \\
\hline & & Class 4 & 0 & 0 & 0 & 0 & 0 & \\
\hline & & Class 5 & 0 & 0 & 0 & 0 & 0 & \\
\hline & & Class 6 & 0 & 0 & 0 & 0 & 0 & \\
\hline & \multicolumn{2}{|l|}{ Total } & 16 & 0 & 0 & 0 & 16 & \\
\hline
\end{tabular}

Table 3: Skin prick test IgE and its relation to gender of asthmatic patients and control group

\begin{tabular}{|c|c|c|c|c|c|c|c|c|}
\hline \multirow{2}{*}{\multicolumn{3}{|c|}{ Sex }} & \multicolumn{5}{|c|}{ Skin Test } & \multirow[b]{2}{*}{$P$ value } \\
\hline & & & \multirow{2}{*}{$\begin{array}{c}-\mathrm{Ve} \\
5 \\
\end{array}$} & \multirow{2}{*}{$\begin{array}{c}\text { Low } \\
2 \\
\end{array}$} & \multirow{2}{*}{$\begin{array}{c}\text { Moderate } \\
0\end{array}$} & \multirow{2}{*}{$\begin{array}{c}\text { High } \\
0 \\
\end{array}$} & \multirow{2}{*}{\begin{tabular}{|c|} 
Total \\
7 \\
\end{tabular}} & \\
\hline Female & Test Results & Class 0 & & & & & & \\
\hline & & Class 1 & 0 & 4 & 2 & 0 & 6 & \\
\hline & & Class 2 & 0 & 4 & 3 & 0 & 7 & .000 \\
\hline & & Class 3 & 0 & 0 & 4 & 0 & 4 & \\
\hline & & \begin{tabular}{|l|} 
Class 4 \\
\end{tabular} & 0 & 0 & 1 & 0 & 1 & \\
\hline & & \begin{tabular}{|l} 
Class 5 \\
\end{tabular} & 0 & 0 & 1 & 0 & 1 & \\
\hline & & Class 6 & 0 & 0 & 0 & 1 & 1 & \\
\hline & Total & & 5 & 10 & 11 & 1 & 1 & \\
\hline
\end{tabular}


International Journal of Science and Research (IJSR)

ISSN (Online): 2319-7064

Index Copernicus Value (2013): 6.14 | Impact Factor (2014): 5.611

\begin{tabular}{|c|c|c|c|c|c|c|c|c|}
\hline \multirow[t]{2}{*}{ Male } & \multirow{2}{*}{$\begin{array}{l}\text { Test } \\
\text { Results }\end{array}$} & Class 0 & 7 & 2 & 0 & 0 & 9 & \\
\hline & & Class 1 & 1 & 4 & 2 & 0 & 7 & \\
\hline & & Class 2 & 3 & 0 & 2 & 0 & 5 & .000 \\
\hline & & Class 3 & 0 & 0 & 2 & 0 & 2 & \\
\hline & & Class 4 & 0 & 0 & 5 & 1 & 6 & \\
\hline & & Class 5 & 0 & 0 & 1 & 3 & 4 & \\
\hline & & Class 6 & 0 & 0 & 0 & 4 & 4 & \\
\hline & Total & & 11 & 6 & 12 & 8 & 8 & \\
\hline
\end{tabular}

Table 4: Skin prick test, $\mathrm{IgE}$ and its relation to age groups of asthmatic patients and control group

\begin{tabular}{|c|c|c|c|c|c|c|c|c|}
\hline & $\Delta a \rho$ & & & & in Test & & Total & $P$ volup \\
\hline & Age $g$ & & $-V e$ & Low & Moderate & High & Horat & I value \\
\hline Group1 & Test Results & Class 0 & 0 & 0 & 0 & 0 & 0 & \\
\hline & & Class 1 & & & & & 2 & \\
\hline & & Class 2 & 0 & 1 & 1 & 0 & 2 & .156 \\
\hline & & Class 3 & 0 & 0 & 0 & 0 & 0 & \\
\hline & & Class 4 & 0 & 0 & 0 & 0 & 0 & \\
\hline & & Class 5 & 0 & 0 & 0 & 1 & 1 & \\
\hline & & Class 6 & 0 & 0 & 0 & 2 & 2 & \\
\hline & Total & & 0 & 3 & 1 & 3 & 6 & \\
\hline Group 2 & Test Results & Class 0 & 4 & 1 & 0 & 0 & 5 & \\
\hline & & Class 1 & 0 & 4 & 3 & 0 & 7 & \\
\hline & & Class 2 & 1 & 2 & 2 & 0 & 5 & \\
\hline & & Class 3 & 0 & 0 & 4 & 0 & 4 & .000 \\
\hline & & Class 4 & 0 & 0 & 4 & 0 & 4 & \\
\hline & & Class 5 & 0 & 0 & 1 & 2 & 3 & \\
\hline & & Class 6 & 0 & 0 & 0 & 2 & 2 & \\
\hline & Total & & 5 & 7 & 14 & 4 & 30 & \\
\hline Group3 & Test Results & Class 0 & 8 & 2 & 0 & 0 & 10 & .029 \\
\hline & & Class 1 & 0 & 2 & 1 & 0 & 3 & \\
\hline & & Class 2 & 2 & 1 & 2 & 0 & 5 & \\
\hline & & Class 3 & 0 & 0 & 2 & 0 & 2 & \\
\hline & & Class 4 & 0 & 0 & 2 & 1 & 3 & \\
\hline & & Class 5 & 0 & 0 & 1 & 0 & 1 & \\
\hline & Total & Class 6 & 10 & 5 & 8 & 1 & 23 & \\
\hline Group 4 & Test Results & Class 0 & 0 & 1 & 0 & 0 & 1 & \\
\hline & & Class 1 & 1 & 0 & 0 & 0 & 1 & .199 \\
\hline & & Class 2 & 0 & 0 & 0 & 0 & 0 & \\
\hline & & Class 3 & 0 & 0 & 0 & 0 & 0 & \\
\hline & & Class4 & 0 & 0 & 0 & 0 & 0 & \\
\hline & & Class 5 & 0 & 0 & 0 & 0 & 0 & \\
\hline & & Class 6 & 0 & 0 & 0 & 1 & 1 & \\
\hline & Total & & 1 & 1 & 0 & 1 & 3 & \\
\hline
\end{tabular}

Volume 4 Issue 11, November 2015 


\section{International Journal of Science and Research (IJSR) \\ ISSN (Online): 2319-7064}

Index Copernicus Value (2013): 6.14 | Impact Factor (2014): 5.611

Table 5: Skin prick test and IgE and its relation to residence of studied cases

\begin{tabular}{|c|c|c|c|c|c|c|c|c|}
\hline \multirow{2}{*}{\multicolumn{3}{|c|}{ Residence }} & \multicolumn{4}{|c|}{ Skin Test } & \multirow{3}{*}{$\begin{array}{c}\text { Total } \\
7 \\
\end{array}$} & \multirow{2}{*}{$P$ value } \\
\hline & & & \multirow{2}{*}{$\frac{-V e}{4}$} & \multirow{2}{*}{$\begin{array}{c}\text { Low } \\
3\end{array}$} & \multirow{2}{*}{$\begin{array}{c}\text { Moderate } \\
0\end{array}$} & \multirow{2}{*}{\begin{tabular}{|l} 
High \\
\\
\end{tabular}} & & \\
\hline \multirow[t]{8}{*}{ Rural } & \multirow{7}{*}{$\begin{array}{l}\text { Test } \\
\text { Results }\end{array}$} & Class 0 & & & & & & \\
\hline & & Class 1 & 0 & 3 & 2 & 0 & 5 & \\
\hline & & Class 2 & 0 & 3 & 2 & 0 & 5 & \\
\hline & & Class 3 & 0 & 0 & 4 & 0 & 4 & .000 \\
\hline & & Class 4 & 0 & 0 & 6 & 1 & 7 & \\
\hline & & Class 5 & 0 & 0 & 0 & 1 & 1 & \\
\hline & & Class 6 & 0 & 0 & 0 & 5 & 5 & \\
\hline & \multicolumn{2}{|l|}{ Total } & 4 & 9 & 14 & 7 & 7 & \\
\hline \multirow[t]{6}{*}{ Urban } & \multirow{5}{*}{$\begin{array}{l}\text { Test } \\
\text { Results }\end{array}$} & Class 0 & 8 & 1 & 0 & 0 & 9 & \\
\hline & & Class 1 & 1 & 5 & 2 & 0 & 8 & \\
\hline & & Class 2 & 3 & 1 & 3 & 0 & 7 & \\
\hline & & Class 3 & 0 & 0 & 2 & 0 & 2 & .000 \\
\hline & & Class 5 & 0 & 0 & 2 & 0 & 4 & \\
\hline & Total & Class 6 & $\begin{array}{c}0 \\
12\end{array}$ & $\begin{array}{l}0 \\
7\end{array}$ & $\begin{array}{l}0 \\
9\end{array}$ & $\begin{array}{l}0 \\
0\end{array}$ & $\begin{array}{c}0 \\
30\end{array}$ & \\
\hline
\end{tabular}

\section{Discussion}

House dust mites (HDMs) are important sources of indoor allergens Spieksma and Dieges (2004). Sensitization to HDM in the general population is $9-16 \%$ Squillace et al., (1997). HDM are major allergen sources for almost 50\% of allergic patients De Blay et al., (1994).

In the present study, we aimed to define the prevalence of sensitization to Der p1, Der f1 among patients with atopic asthma in Qena Governorate.

In the present study132 asthmatic patients children and adults who was diagnosed as asthma according to (GINA) guidelines, skin prick test were done to them and it was positive to HDM (Dermatophagoides pteronyssinus (Der p1) and Dermatophagoides farinae (Der f1) in 48 patients (36. 36\%), while skin prick test in control group was $15.78 \%$ with a significant difference ( $\mathrm{P}$ value is 0.015$)$ (table 1) and this agree with a study by Helal et al., (1999) they found sensitivity to HDM by skin prick test was $32.4 \%$, also Mohamed et al.,(2000) in a study on asthmatic patients at Assuit Governorate sensitivity to HDM by skin prick test was 35\% and Gutarowska et al., (2005) found that $38.8 \%$ of allergic patients had positive skin prick test to HDM. Lee et al., (2008) stated that the sensitivity to Dermatophagoides pteronyssinus (Der p1) $26.6 \%$ and to Dermatophagoides farinae (Der f1) 22.7\% which more or less agree with the results obtained in the present study, also Castro-Almarales et al., (2006) in a study done on Cubans asthmatic patients stated that sensitivity to (Dermatophagoides pteronyssinus (Der p1) and Dermatophagoides farina (Der f1) was 31.9\%.
On the hand Kamal et al., (2008) in a study done at Sohag Governorate found that sensitivity to Dermatophagoides pteronyssinus (Der p1) was 52\%, El- Shinawy et al., (1989) conducted that $80 \%$ of asthmatic patients were sensitive to Dermatophagoides pteronyssinus (Der p1) which was higher than the results obtained in the present work.

Der $\mathrm{p} 1$ and Der f 1 are cysteine proteases with multiple effects on mite-host interaction. These proteases facilitate allergen delivery to the sub-mucosa and its antigenpresenting cells, leukocyte recruitment and activation, including mast cell and eosinophil degranulation, bronchial smooth muscle contraction and proliferation (Gregory and Lloyd (2011), Jacquet (2011), Lambrecht and Hammad (2009) and Miglino et al., (2011).

In the present study, we measure specific IgE for Dermatophagoides pteronyssinus (Derp1) and Dermatophagoides farinae (Der f1) to asthmatic patients and healthy control group, so blood samples for IgE assay of Immuno CAP asthmatic patients, and we found that there was a significant relation between serum specific IgE to Der $\mathrm{p} 1$ and Der f1 in patients in comparison to control group where specific IgE to Der p1 and Der f1 detected in $91.66 \%$ in asthmatic patients while it was $25 \%$ in control group( $\mathrm{P}$ value is 0.000$)$, also there was a significant correlation between skin prick test and the levels of $\operatorname{IgE}$ to Derp1 and Derflwhere its level was high with moderate and higher with strong positive skin prick test and its level was low or negative with low skin prick test ( $\mathrm{P}$ value is $0.000)$, finding and control group this agree with Hala et al., (2007) they reported that the level of serum $\operatorname{IgE}$ concentration increase in allergic patients in comparison to healthy population also Haung et al., (2006).

In the present study there were no difference in sensitivity to HDM (Der p1 and Der f1) to both male and female asthmatic patients and it was highly significant ( $\mathrm{P}$ value is 0.000 ) and this may be attributed to somewhat to the 


\section{International Journal of Science and Research (IJSR) \\ ISSN (Online): 2319-7064}

Index Copernicus Value (2013): 6.14 | Impact Factor (2014): 5.611

limited number of the studied patients. Tang et al., (1995) who revealed that male gender had a higher frequency of sensitization to HDM, also Liccardi et al., (1998) stated that there was a higher percentage of sensitization to HDM among the male gender.

In the present study sensitivity to Der $\mathrm{p} 1$ and Der $\mathrm{fl}$ in relation to age groups there were a high significant correlation in age group 2 ( $\mathrm{P}$ value is 000) and low significant correlation ( $\mathrm{P}$ value is 0.029 ) while there were no significant relation among age groups 1 and $4(\mathrm{P}$ value is 0.156 ) and ( $\mathrm{P}$ value is 0.199 ) respectively. In a study on Taiwanese atopic children they stated that sensitization to Der p1 and Der f1was $90.2 \%$ and $88.2 \%$ respectively. Also according to a study involving French children in 2012, prevalence of Der p 1 sensitization was 95\% Bronnert et al., (2012). In another study involving Austrian children and adults, prevalence of Der p 1 sensitization was $91 \%$ Pittner et al., (2004). Another study conducted in Singapore, which has a tropical climate, reported Der p1 sensitization prevalence of $64 \%$ of the studied population Kidon et al., (2011). While in a study done by Hwan et al., (2015) the prevalence of sensitization in Korean children to Der p was $98.8 \%$, Der f was $100 \%$, Der p 1 was $82.5 \%$, and there were a marked difference in the present work in comparison to the results obtained by the previous studies and this may be due to all the previous studies done on children only while our study done on the all age groups, so we recommend to select to study only children in another studies.

In according to residence of the studied patients and control group sensitivity to Der p1 and Der f1 was highly significant correlation ( $\mathrm{P}$ value is 000$)$ in both rural and urban residence of the studied patients but sensitivity to Der $\mathrm{p} 1$ and Der $\mathrm{fl}$ were more severe in rural patients.

In the present study, Der $\mathrm{p} 1$ and Der flsensitization rates were more or less equal to previous studies but the strongpoint of our study lies in the fact that Immuno CAP was used to determine specific IgE while Previous studies usually used allergen dot immune-blot arrays that are known to be prone to nonspecific IgE binding as well as nonspecific inhibition of IgE binding by the presence of large quantities of antigen specific IgG in patients sera Fonseca et al., (2009) and Bronnert et al., (2012).

\section{Conclusion}

Sensitization to HDM and its components in Egyptian asthmatic patients is similar to previous studies from temperate climate and all over the world. The determination of Der $\mathrm{p} 1$ and Der f1IgE helps in obtaining additional information about role of HDM in atopic asthma and other allergic disease which may help in treatment and control of asthma.

\section{References}

[1] Arlian L. G., Platts-Mills T. A., (2001): The biology of dust mites and the remediation of mite allergens in allergic disease. J. Allergy Clin. Immunol.; 107: S406413.
[2] Bronnert M., Mancini J., Birnbaum J., Agabriel C., Liabeuf V., Porri F., Cleach I., Fabre A., Deneux I., Grandne V., Grob J. J., Berbis P., Charpin D., Bongrand P., Vitte J., (2012): Component-resolved diagnosis with commercially available $\mathrm{D}$. pteronyssinus Der $\mathrm{p} 1$, Der $\mathrm{p} 2$ and Der $\mathrm{p}$ 10: relevant markers for house dust mite allergy. Clin. Exp. Allergy .42: 1406-1415.

[3] Castro- Almarales R. E., Mateo M.. M., Naranjo , Robalino R. M. Navarro Viltre BI, Alvarez C. M., Ronquillo D. M., García G. I.,Oliva D. Y., González L. M., Rodríguez C. J. S. andLabrada R. A., (2006): Correlation between skin tests to Dermatophagoides pteronyssin -us ,Dermatophagoides siboney and Blomia tropicalis in Cuban asthmatics. Allergol Immuno- pathol. (Madr)., 34 (1) :23-26.

[4] De Blay F., Pauli G., Velten M., Bessot J. C., (1994): Influence of mite exposure on symptoms of mitesensitive patients with asthma. J. Allergy Clin. Immunol. 1994; 93 (1 Pt 1):136-138.

[5] El- Shnawy O., Salem E. S. and Hammad H. E., (1989)): The role of some important inhalant antigens in the allergic broncho-pulmonry conditions in Upper Egypt. MD Thesis, Chest Disease. Assiut Faculty of Medicine- Assiut Univesity.

[6] Fernandez-Caldas E., (2002): Dust mite allergens: mitigation and control. Curr. Allergy Asthma Rep.; 2:424-431.

[7] Ferreira F., Wallner M., Breiteneder H., Hartl A., Thalhamer J. and Ebner C., (2002): Genetic engineering of allergens: future therapeutic products. Int. Arch. Allergy Immunol. 128:171-178.

[8] Fonseca P., Tavares- Ratado P. and Tomaz C. T., (2009): Interference of Dermato-phagoides' specific immuno- globulins $\mathrm{G}$ in the quantification of mite's specific immunoglobulins. E. J. Immunoassay Immunochem. 30:338-347.

[9] Gregory L. G. and Lloyd C.M., (2011).Orchestrating house dust mite-associated allergy in the lung. Trends Immunol. ; 32:402-411.

[10] Gutarowska B., Wiszniewskka M., Wausiak J., Potrowska M., Palczynski C. and Zakowska Z., (2005): Exposure of moulds in flat and the prevalence of allergic disease preliminary study. Pol. J. Microbiol., 45:13-20.

[11] Hala A. E., Samar N., Manar S. A., TarekKh. Z., Hany M. E., Abdelbaset M. S. and Atef M. E., (2007): Diagnostic criteria for house dust mites sensitized allergic patients. Egypt. J. Egypt. Soc. Parasitol., 37(3): 1113-1124.

[12] Helal M. Z., Samir M. M., Manar and Abdel Rahman A. T., (1999): The potential role of macrophage migration inbittiroy factor in house dust nasal allergy. Egypt.J. Immunol., 6 (1): 143-148.

[13]Huang C. I., Liew L. M. Mah K. W., Kuo I. C., Lee B. W. and Chua K. Y., (2006): Characterization of glutathione S-transferase from dust mite, Der $\mathrm{p} 8$ and its immunoglobulin E cross reactivity with cockroach glutathione S-transferase. Clin. Exp. Allergy., 36 (3):369- 376

[14]Hwan S. K., Sung H. K., Sulmui W., Eu K. L., Yoon H. C., Jong-Seo Y., Hyun H. K., and Jin T. K., (2015): Immunoglobulin $\mathrm{E}$ to allergen components of house 


\section{International Journal of Science and Research (IJSR) \\ ISSN (Online): 2319-7064}

Index Copernicus Value (2013): 6.14 | Impact Factor (2014): 5.611

dust mite in Korean children with allergic disease. Asia. Pac. Allergy. ; 5(3): 156-162.

[15] Jacquet A., (2011): The role of innate immunity activation in house dust mite allergy. Trends Mol. Med.2011; 17: 604-611.

[16] Kamal A. A., Ismail S. M., Azza M., Mohamad S. and Zenab M. D., (2008): The diagnostic value of skin prick test Blood Eosinophiia and Serum IgE Level in Atopic Bronchial Asthma. Egyptian J. of CHIST. 57;1:46-58.

[17] Katz N., Chaves A. and Pellegrino J., (1972): A simple device for quantitative stool thick-smear technique in schistosomiasis mansoni. Rev. Inst. Med. Trop. Sao Paulo; 14: 397-400.

[18]Kidon M. I., Chiang W. C., Liew W. K., Ong T. C., Tiong Y. S., Wong K. N., Angus A. C., Ong S. T., Gao Y. F., Reginald K., Bi X. Z., Shang H. S., Chew F. T., (2011): Mite component-specific IgE repertoire and phenotypes of allergic disease in childhood: the tropical perspective. Pediatr. Allergy Immunol. : 22: 202-210.

[19]Kim H. R, Lee D. M, Lee S. H, Seong A. R, Gin D. W., Hwang J. A., Park J. H., (1010): Chlorogenic acid suppresses pulmonary eosinophilia, IgE production, and Th2-type cytokine production in an ovalbumininduced allergic asthma: activation of STAT-6 and JNK is inhibited by chlorogenic acid. Int. Immunopharmacol. 10:1242-1248.

[20]Lambrecht B. N. and Hammad H., (2009): Biology of lung dendritic cells at the origin of asthma. Immunity. $31: 412-424$.

[21] Lau S., Illi S., Sommerfeld C., Niggemann B., Bergmann R., von Mutius E.,

[22] Wahn U., (2000): Early exposure to house-dust mite and cat allergens and development of childhood asthma: a cohort study. Multicentre Allergy Study Group. Lancet; 356:1392-7.

[23] Lee JS, Kim IS, Ryu JS, Yun CY (2008): House dust mite, Dermatophagoides pteronissinus increases expression of MCP-1, IL-6, and IL-8 in human monocytic THP-1 cells. Cytokine 42: 365-371. doi: 10.1016/j.cyto.2008.03.010

[24] Li Y. and Hua S., (2014): Mechanisms of pathogenesis in allergic asthma: role of interleukin 23. Respirology.19:663-669.

[25] Liccardi G., Russo M., D’Amato M., Granata F. P., De Napoli A. and D'Amato G., (1998): Sensitization to cockroach allergens in a sample from the urban population living in Naples (southern Italy).J. Investig.Allergol.Clin.Immunol.8:245-8.

[26] Miglino N., Roth M., Tamm M.and Borger P., (2011): House dust mite extract down-regulates $\mathrm{C} / \mathrm{EBP} \alpha$ in asthmatic bronchial smooth muscle cells. Eur. Respir. J. 38:50-58.

[27] Mohamed A., Osman A. H., and Sayed S., (2000): Role of immunotherapy and antihistamines in allergic bronchial asthma. MD Thesis. Chest Disease. Assiut Faculty of Medicine- Assiute Univesity.

[28] Montealegre F., Meyer B., Chardon D., Vargas W., Zavala D., Hart B., Bayona M., (2004): Comparative prevalence of sensitization to common animal, plant and mould allergens in subjects with asthma, or atopic dermatitis and/or allergic rhinitis living in a tropical environment. Clin. Exp Allergy. 2: 34:51-8.

[29] National Institutes of Health, National Heart, Lung, and Blood Institute (2002): Bethesda, MD, USA.Diagnosis and Classification. In: Global Strategy for Asthma Management and Prevention: 67-76.

[30] Official abstracts of papers of the XIII International Congress of Allergology and Clinical Immunology (ICACI) (1988): October 16-21, Montreux, Switzerland. N. Engl. Reg. Allergy Proc. 9: 249-521.

[31] Paganelli R., Ansotegui I. J., Sastre J., Lange C. E., Roovers M. H., de Groot H., Lindholm N. B., Ewan P. W., (1998): Specific IgE antibodies in the diagnosis of atopic disease. Clinical evaluation of a new in vitro test system, UniCAP, in six European allergy clinics. Allergy: 53:763- 8.

[32] Pastorello E. A., Incorvaia C., Ortolani C., Bonini S., Canonica G. W., Romagnani S., Tursi A., Zanussi C., (1995): Studies on the relationship between the level of specific IgE anti- bodies and the clinical expression of allergy: I. Definition of levels distinguishing patients with symptomatic frompatients with asymptomatic allergy to common aeroaller- gens. $J$. Allergy Clin. Immunol. ; 96:580-7.

[33] Pittner G., Vrtala S., Thomas W. R., Weghofer M., Kundi M., Horak F., Kraft D., Valenta R., (2004): Component-resolved diagnosis of house-dust mite allergy with purified natural and recombinant mite allergens. Clin. Exp. Allergy. 34:597-603.

[34] Platts-Mills T. A., Thomas W. R., Aalberse R. C., Vervloet D. and Champman M. D., (1992): Dust mite allergens and asthma: report of a second international workshop. J. Allergy Clin. Immunol. 89:1046-1060.

[35] Spieksma F. T and Dieges P. H., (2004):The history of the finding of the house dust mite. J. Allergy Clin. Immunol.113:573-576.

[36] Sporik R., Holgate S. T., Platts-Mills T. A., Cogswell J. J., (1990): Exposure to house-dust mite allergen (Der p I) and the development of asthma in childhood.A prospective study. N. Engl. J. Med.; 323:502-7.

[37] Squillace S. P., Sporik R. B., Rakes G., Couture N., Lawrence A., Merriam S., Zhang J. andPlatts-Mills A.E., (1997): Sensitization to dust mites as a dominant risk factor for asthma among adolescents living in central Virginia.Multiple regression analysis of a population-based study. Am. J. Respir. Crit. Care Med. 156:1760-1764.

[38] Tang R. B., Tsai L. C., Hwang H. M., Hwang B., Wu K. G., Hung M. W., (1990): The prevalence of allergic disease and $\mathrm{IgE}$ antibodies to house dust mite in schoolchildren in Taiwan. Clin. Exp. Allergy 1990: 20: 33-8.

[39] Wahn U., Lau S., Bergmann R., Kulig M., Forster J., Bergmann K., Bauer C. P., Guggenmoos-Holzmann I., (1997): Indoor allergen exposure is a risk factor for sensitization during the first three years of life. $J$. Allergy Clin. Immunol; 99:763-9

[40] Yasue M., Yokota T., Yuasa M., Kajiwara Y., Suko M., Okudaira H., (1998): Effects of oral hyposensitization with recombinant Der f2 on immediate airway constriction in a murine allergic model. model. Eur. Respir. J. 11:144-150 